\title{
LEGAL PLURALISM, CUSTOMARY LAW AND HUMAN RIGHTS IN FRANCOPHONE AFRICAN COUNTRIES
}

\author{
Jacques Frémont*
}

This article provides a perspective on human rights in sub-Saharan Africa, with an emphasis on states colonised and influenced by the continental cultures of France and Belgium. The author examines what the Pacific can gain from the Francophone countries' understanding of human rights, with insights into the interface of cultures in post-colonial statehood. The article is one of four background papers which provide paradigms and challenges for a possible Pacific charter.

\section{INTRODUCTION}

In the age of globalisation, Africa is an often forgotten continent that generally draws little interest in the political, media and academic worlds. When one hears about the continent or one of its countries, it is generally about disasters, wars or famine, rarely about the richness and the diversity of its people, the beauty of the continent or the formidable diversity and co-operative unity of its societies. In that same age of globalisation, it is striking how little jurists and legal academics know about the legal systems of Africa. This article will show that much is to be gained from our understanding of contemporary legal systems from the effective functioning of sub-Saharan legal systems and, particularly, Francophone countries.

Africa is probably today's largest living laboratory of effective legal pluralism. Its understanding allows for a different reading of legal pluralism even within Western and Northern societies. For other societies struggling with the impact of international norms on the internal legal orders, the comprehension of the richness and the limits of legal pluralism can also provide keys to the potential, and to the limits, of the combination of local norms with the imperatives flowing from the emerging international legal order. It is particularly true in the human rights sector.

* Professor of Law and Provost, Université de Montréal, Canada. The author wishes to thank Georges Naskseunguefang and Anthony Ramarolanihaingonirainy who have produced documents and analysis which supported this paper. Any omission or error remains that of the author. 
It is, of course, somehow unfair to the complexity and the diversity of Africa's legal systems to boil them down to a few pages barely drawing on the main aspects of the continental and local legal systems, with a view to presenting the zones of interface between contemporary human rights on the one hand and traditional customary laws on the other.

This article will mainly focus on Sub-Saharan Africa, deliberately leaving aside the Maghreb northern African countries, including Libya and Egypt which, from times immemorial, have had quite distinct legal systems heavily influenced by Muslim normative approaches. Within SubSaharan African countries, we will focus on the countries under the Francophone zone of influence. At colonisation, their legal systems were marked by the continental influence (France and Belgium) while many other African countries fell under the British common law based approach. In many respects, in colonial and post-colonial days, the Francophone and Anglophone legal systems have influenced the evolution of the "official" legal systems in quite different (but in some respects converging) directions. These Francophone countries can be geographically regrouped as Western Africa (Bénin, Burkina Faso, Cap-Vert, Côte-d'Ivoire, Guinée, Guinée-Bissau, Mali, Mauritania, Niger, Sénégal and Togo); Central Africa (Burundi, Cameroon, République Centre-Africaine, Congo, République Démocratique du Congo, Gabon, Guinée-équatoriale, Rwanda, Sao Tomé et Principe and Tchad); and Eastern African and the Indian Ocean (Comores, Djibouti, Madagascar, Mauritius and Seychelles).

\section{SOME CHARACTERISTICS OF AFRICAN LEGAL SYSTEMS}

In traditional African societies, the individual citizen is primarily seen as a link of a communitychain. Even today, all over Africa, the people essentially form a community-based culture: the full respect of social order and the necessity to achieve group harmony are crucial values which must be maintained. Social harmony, solidarity and community values are thus to be preserved at all costs. In African societies, the duty of solidarity has played and continues to play a major role in the establishment of behavioural norms, which are usually very constraining. For all purposes, they organise the life of the family, the clan and the village. The translation of such solidarities, ideally, should be found in legal norms.

It is not surprising, in this context, to note that the pre-existing colonial legal systems reflected these values and that even today these values can still be found in the official legal systems of most African countries. It is no more surprising that the African population forms essentially a rural society and remains on a day-to-day basis under their traditions' direct influence, somehow resistant to the rules and approaches of modern law.

\section{A Traditional African Legal Systems}

The characteristics of the traditional African legal systems are well identified. They have to do, mainly, with the unwritten nature of the traditional customary system and also with the values generally enshrined in the customary systems. 


\section{Unwritten legal systems}

The primary characteristic of African legal systems is undoubtedly the unwritten nature of the customary norms. It probably explains why, over the course of history, many have considered that there were no legal systems in Africa before colonisation. Some authors, on the other hand, maintain that the African legal system was also made of written laws, jurisprudence and doctrine. ${ }^{1}$ The reality is probably that, for all purposes, the pre-colonial legal system was essentially based on unwritten customary law. It means that it was - and still is - difficult to know the precise contents of the legal norms in question; ${ }^{2}$ they were deposited with elders and transmitted from generation to generation. It is interesting to note that in the 20th century, French authorities compiled the customary laws of the various African peoples under French jurisdiction; they can still be used today to understand the state of customary law. ${ }^{3}$

The reality is that today, this unwritten legal system is also widely applied in the official legal systems of many countries through the use of assessors who have a duty to assist the judge in understanding what the customary law is in a given situation. Even though this technique is not without problems, it provides an interface between the official and customary legal orders. ${ }^{4}$ The impact of customary laws is also felt in many written laws when introduced, whether by the colonial authorities or, later, by the national legislator.

\section{Communitarian values}

Another important characteristic of African customary systems concerns their communitarian values. ${ }^{5}$ The first and foremost value on the continent is the preservation of social peace within the community. It is explained by the fact that for these societies, being mobile and lacking strong organisation, it became essential to solve any conflict in order to avoid tensions between members of the society. Social harmony thus became a privileged value for societies that faced challenges and difficulties from the outside. African customary law became a necessary tool allowing the achievement of social harmony.

It follows that in cases of conflict, resolution will not come from judges deciding between two parties, but rather from a conciliatory process conducted by the community, between the diverging interests with a view of favouring harmony. The process is associated with palabra: it is held in

1 Jacques Vanderlinden Les Système Juridiques Africains (Presses Universitaires de France, Paris, 1983 ) 9.

2 Fatsah Ouguergouz La Charte Africaine des Droits de l'Homme et des Peuples: Une Approche Juridique des Droits de l'Homme Entre Tradition et Modernité (Presses Universitaires de France, Paris, 1993) 7.

3 See for instance Divers Coutumiers Juridiques de l'Afrique Occidentale Française, Tome 1: Sénégal, Tome 2: Soudan (Larose Éditeurs, Paris, 1939).

4 Vanderlinden, above n 1, 12.

5 Ibid, 22 
public, often takes much time and aims at, ultimately, drawing the community's as well as the litigants' adherence to the solution identified. This process meant that no judges, written norms, hierarchy or specialised conflict resolution institutions were used in the traditional pre-colonial system.

\section{B Colonial and Post-Colonial African Legal Systems}

Foreign influences on African legal systems have diversified over the centuries. In pre- and post-colonial times, they included Muslim, Copt, Romano-Flemish, Asian and American influences. In colonial times, the legal systems fell under Belgian, British, French, Portuguese and Spanish dominance. Traditional legal systems have been influenced often by more than one of these foreign systems. It explains why it is difficult to draw definite conclusions about the state of today's African legal culture.

Colonial history and legal orders have been imposed in a disorderly fashion: often neighbouring countries have possessed very different legal systems even if the countries are inhabited by the same ethnic peoples. In some cases, the same countries have two or three colonisations and as many legal orders superimposed the one upon the other. Since the end of colonisation in Africa, one has to admit that the legal systems have been built on legal supports which have also been heavily influenced by other legal cultures; African states tend to import within their legal systems and institutions the models of Western developed countries.

The relative alienation flowing from the imposition of norms and institutions alien to the population's culture is not surprising in this context. The inadequacy of the models imposed on local realities, the ill-functioning of the institutions and the relative non-legitimacy of these institutions do cause difficulties in today's African countries. However, the principle of the rule of law cannot be done without. Despite a certain crisis of legitimacy, the state of development of African countries must make do with these "imposed" norms.

\section{THE INTERFACE BETWEEN TRADITIONAL AND MODERN APPROACHES}

Traditional and modern approaches therefore interact with each other in different fashions. For the purpose of this article, we will discuss three areas where the interface is of particular relevance: those of norms and conflict resolution of the roles of power structures and institutions and of processes.

\section{A Norms and Conflict Resolution}

\section{Norm pluralism in contemporary Africa}

The first area of interface between traditional and modern legal systems in various African countries surrounds norms and the resolution of conflicts around these norms. We have seen that it is difficult to comprehend what the law was like in pre-colonial societies; African law varied from 
one group to another and norms were not written. It is clear, however, that many of these traditional norms have over the years been noted at some point by the colonial or modern post-colonial systems. Sometimes they have been replaced or modified; at others they have remained more or less untouched.

Vanderlinden in an enlightening passage explains the interpenetration of colonial and traditional norms over the ages. ${ }^{6}$ He shows that in many cases, the colonial authorities chose to impose public law while allowing for traditional private law to survive, leaving intact the fundamental sphere of social and community life. In other cases, colonial authorities have squarely refused to recognise and allow for traditional rules to subsist (such as allowing marriage for children or polygamy) as against public order. In other words, colonial authorities would let traditional laws survive providing they did not violate rules of natural justice or public decency (according to colonial authorities). "Offensive" traditional rules were reformed or set aside. The influence of traditional norms has generally been restricted to private law, while public law, including penal law, was left to the state and applied mainly in urban areas and for some expatriates, thus having a somewhat restricted influence. ${ }^{7}$

However, one of the more significant influences of traditional norms is felt in parts of the countryside where customs are established and followed by the whole population; therefore, customary rules must be treated as equivalent to law especially in family law and property law. It means that in the same territory, different sets of norms co-exist and are applicable to the individual who has to follow traditional (for instance in family and succession matters) as well as modern norms. The traditional norms are still of particular importance within the family, clan and village; they tend to lose some of their influence in urban areas where they are replaced by official legal norms.

In this context, it means that traditional conflict mechanisms still have some relevance, especially within the community and the village, and that the traditional chiefs, who are in charge of making and interpreting the law, are holders of power, even within modern African societies.

\section{Palaver and traditional conflict resolution mechanisms}

Conflict resolution is usually as important as the norms applied in any given society; conflict resolution mechanisms ${ }^{8}$ have to be somehow in tune with the society they serve. As indicated above, it was seen as crucial to maintain equilibrium and harmony within the group, even in the

$6 \quad$ Vanderlinden, above n $1,87$.

7 Ibid, 97

8 Jean Matringue Tradition et Modernité dans la Charte Africaine des Droits de l'Homme et des Peuples, Étude sur le Contenu Normatif de la Charte et de son Apport à la Théorie du Droit International des Droits de l'Homme (Bruylant, Bruxelles, 1996) 69. 
presence of conflicts between some of its members. In Africa, traditional conflict resolution mechanisms allowed different generations of members of the group, organised in age groups, to participate in the debates led by elders. Elders symbolise wisdom as well as expertise in history, customary law and esotericism. In such cases, the conflict must not be resolved by an authority deciding who is right or wrong according to pre-established rules of law as understood and interpreted by any given judge. Rather, it must be solved by the litigants themselves with the help of the community, in a collective process where the conflict will be solved with a view of attaining harmony, equilibrium within the group and between the litigants, and according to the guiding principles of customary law.

In the process, negotiations, discussions, and exchanges occur in order to encourage the emergence of compromises between the opposing parties. Dialogue is thus the preferred means of solving disputes. ${ }^{9}$ The process tends to encourage go-between propositions and counterpropositions in order to reach a compromise. In resolving the conflict, sacrifice must be present, and fair and just compensation will be expected from the party at fault. Exchanges can be very stiff and long lasting. ${ }^{10}$

The conciliatory authority overseeing the process might be the village chief, the group chief, the tribal chief or even the King; the authority will be chosen according to the type of conflict. It can be assisted by a notables' council. The authority's ultimate mission is to get the parties closer, to preserve social equilibrium and help parties to find a solution. The parties are allowed to present

9 Lanciné Sylla Démocratie de L'arbre à Palabre et du Bois Sacré, Essai sur le Pouvoir Parallèle des Sociétés Initiatiques Africainesin Sacralité, pouvoir et droit en Afrique (Annales de l'Université d'Abidjan, Série D: Littérature, Sciences Humaines Abidjan, Paris, 1980) 6 as quoted by B S Ngom Les Droits de l'Homme et l'Afrique (Silex, Paris, 1984) 22: "Le palabre africain apparaît ainsi comme un véritable système de gouvernement conduisant à une certaine forme de démocratie directe,symbolisée de nos jours par l'arbre à palabre, dont l'ombre formait une sorte d'agora naturelle à la gérontocratie, aux chefs et aux grands dignitaires de la nation réunis en conseil devant le peuple tout entier. Cette institution de l'arbre à palabre, qu'on peut qualifier d'universelle en Afrique Noire, pouvait prendre les formes les plus variées, depuis les minuscules conseils des anciens des petites communautés claniques et lignagères, jusqu'à revêtir les caractères d'un véritable parlement, véritable conseil du gouvernement, véritable conseil exécutif ou présidium suprême, comme l,Ashanti Kotobo de la célèbre Confédération Ashanti de l'actuel Ghana,le grand conseil hautement hiérarchisé du Morho-Naba du royaume de Ouagadougou en Haute-Volta (Burkina Faso), ou le Loukiko bougandais, parlement royal des Kabakas de l'ancien royaume des Bouganda en Ouganda."

10 R Cornevin as quoted by Sylla, above n 9, 4: "Le palabre africain obéit à des règles strictes et dure souvent longtemps, car aucune restriction n'est apportée au discours des assistances de toute origine. Cette lenteur provient de la trop grande liberté qu'a chacun de dire son sentiment, jusqu'aux esclaves qui n'en sont pas exclus... la parole est à quiconque veut le prendre. Les orateurs s'expriment généralement avec la plus grande franchise. Il est convenu que, dans ces occasions, les chefs doivent s'entendre dire les choses les plus dures sans froncer les sourcils. Là comme ailleurs, il se trouve toujours un parti qui soutient le pouvoir et un autre qui l'attaque." 
their case themselves, through an orator or with the help of féticheurs (sorcerers). The sanction is determined at the end of the process and might go as far as exclusion from the group.

\section{B The Role of Power Structures and Institutions}

In traditional African societies, the articulation of power structures could be quite elaborate. The ways in which authority was exercised was often quite complex. Traditional chiefs did not have full and discretionary authority over their village or community; power had to be shared and certain equilibrium was sought between the holders of authority.

\section{Traditional chiefs and chieftaincies}

Traditional chiefs still carry considerable weight in many African societies nowadays even if, in fact, they have very little if no power at all, at least officially, under each country's official legal system. It is as if despite official state normativity ignoring them, traditional chiefs manage to exercise a substantial influence over the way villages and societies effectively function. Traditional chieftainships never disappeared completely from power structures in Africa and chiefs still retain some influence over governance in African societies. They have recently been enjoying a certain revival.

The traditional chiefs still influence the life of village members. Their power is so great that it often is in fact exercised over village members living away in towns, or even abroad; they personify justice because they used to be responsible for the group's security and cohesion as soon as a conflict threatened the harmony of social relations. The power of traditional chiefs is as seen as important; village members had to behave with the greatest respect and there could be no conflict between a member of the group and the traditional chief.

The chiefs' legitimacy comes from traditional sources and is of a hereditary nature. Traditional chiefs, in the course of history, have played a somewhat ambiguous role, notably as collaborators with colonial regimes. Of course, their contemporary presence in the social-political and economic life of different African countries may appear contradictory to modern democratic systems where legitimacy flows in great part from the consent of individuals (citizens) as expressed through the electoral system. However, chieftaincies have two main sources of legitimacy. ${ }^{11}$ Their authority flows directly from the traditional legitimacy of the pre-colonial era as well as from colonial times when traditional chiefs had recognised authority flowing from texts. It also flows more significantly from the authority and power from direct links with God and ancestors' spirits.

11 Donald I Ray and Laura Dunham "Autorité Traditionnelle et Autorité Locale au Ghana" (1998) 88 Revue Francaise d'Administration Publique 590, 591. 
Chieftaincies are thus still present and thriving in many African countries. In Burkina Faso, the Moose traditional Chieftaincies are still active; ${ }^{12}$ it is the same in various African countries such as Cameroon, ${ }^{13}$ Togo, Zimbabwe, Lesotho and South Africa. ${ }^{14}$ In Ghana, they are even recognised in the Constitution; ${ }^{15}$ in Ghana, the chiefs exercise official functions in local instances with responsibilities for topics such as the environment, health, social practices, women and other important matters.

\section{The sharing of powers}

One of the most interesting dimensions of traditional power structures in Africa is the existence of counterweights within the village and traditional institutions. The chiefs often delegate their powers to designated underchiefs, conquered underchiefs and notables. The notables are the most powerful persons; they hold hereditary titles and are the keepers of traditions within the village. They share power with the sorcerers, witches and magicians who also hold hereditary titles and are in charge of the magico-religious dimensions of power. In many places, the chief is counselled by a privy council which advises him with regard to applying the rules flowing from ancestral traditions and helps in assuring that the decisions are taken in coherence with lineage. Other counterweights such as secret societies (with various influences - often the occult applying pressure of different sorts) may also exist.

The equilibrium and existence of counterweights within any given society are typical of the contemporary elements of democracy; most of the so-called modern democratic systems rely in great part on this equilibrium to guarantee the proper working of the institutions of the state. It has also been demonstrated that chieftaincies and traditional chiefs are a force to be reckoned with in Africa nowadays. Despite an apparent democratic paradox, their effective legitimacy within their respective societies could certainly offer an opportunity to develop new power structures better articulated with official institutions of power and offer a counterweight in some instances. However, this hypothesis does raise the issue of the interplay between modern and traditional forces. The challenge is for them to complement each other in order to form a power structure capable of arbitrating traditional and modern norms and dispute resolution mechanisms for the greater good of the people.

12 Jean-Baptiste Ouedraogo "The Articulation of the Moose Traditional Chieftaincies, the Modern Political System and the Economic Development of the Kaya Region" (1996) 37-38 Journal of Legal Pluralism 249, 261.

13 Piet Konings "Chieftaincy, Labour Control and Capitalist Development in Cameroon" (1996) 37-38 Journal of Legal Pluralism 329, 346.

14 See Donald I Ray, E B Adriaan, van Rouveroy and van Nieuwaal "The New Relevance of Traditional Authorities in Africa" (1996) 37-38 Journal of Legal Pluralism 1, 38.

15 Ray and Dunham, above n 11, 585 and the Constitution of Ghana, ss 154, 159 and 277. 


\section{Processes}

Processes are very much part of the functioning of all societies whether traditional or modern. The intersection between traditional processes and their modern incarnations reveal the complementary potential of modern and traditional processes as tools of resolving social tensions and disputes within the community. Discursive processes and dispute resolution processes are good examples of this potential.

\section{Palabra, national conferences and democratic interpellation}

It has already been explained that palabra is an intrinsic dimension of the working of traditional African societies. It is remarkable to note that in recent years, the institution of the palabra tree has been used and somehow updated. For instance, in some Francophone West African countries, national conferences were held to collectively discuss the future of the country. These democratic exercises followed the fall of the Berlin Wall. In Benin for instance, the national conference put an end to seventeen years of dictatorship. The conference process was more or less inspired by the palaver tree process and delegates from all quarters of the Benin society participated. Representation, however, was not perfect with an under-representation of women and of traditional chiefs and a corresponding over-representation of politicians and political parties. Such a democratic exercise has been seen as a modern form of palaver tree in giving back to African people their voice after decades of confiscation by political powers. A very important effect of exorcism of former systems and of legitimisation of the new systems followed, allowing a highly symbolic passage from the old to a new system.

In Mali, an original institution flowing from the spirit of the palaver tree has been set up since the transition to democracy in 1991. Every year, on 10 December, a ceremony called the Espace d'Interpellation Démocratique (EID; Democratic Addresses Ceremonial) is held. All members of the Government and the population meet on that day to exchange views on whatever topic they wish. Members of the population can discuss directly and freely with Government ministers during a session which lasts up to fifteen hours. A Commission organises the EID every year and the addresses of the population often tackle subjects including corruption, administrative delays and non-respect of judicial rulings. The session is held publicly in front of ambassadors and foreign guests. Since 2007, the Government has agreed to set up a permanent commission to follow up on the EID's recommendations.

\section{Justice and judicial process}

Officially, traditional justice has been suppressed almost everywhere in Francophone Africa except, maybe, in Cameroon. In fact, the situation is more complex: the problems with modern justice have left many traditional dispute resolution systems intact all over Africa. We have seen that traditional justice remains relatively simple: the procedure is conducted in the justiciable's language and decided under legal rules which are known and understood. 
One will have noticed that many elements of traditional justice are elements of recognised principles of fundamental justice. Traditional justice is based on concertation and dialogue; it aims to resolve a conflict peacefully and without force. The process aims to discover the truth through discussions and exchanges. It costs little or nothing to the parties and is solved impartially. The end result is a sentence based on sacrifice as well as just and fair compensation.

However, many elements of the traditional systems also differ from modern requirements. Traditionally, as mentioned previously, the resolution processes aimed at solutions agreed to by each party as well as cohesion and harmony within the group with a view to preserving collective interests. It follows that discussions and exchanges must allow for compromise through a continuing process of proposals and counter-proposals. The traditional process is based on consensus and the decisions are taken in collegiality. The traditional process is thus very different from modern justice in formal (process) and material (role of judges, of norms) terms and the interrelationship between these.

If traditional justice remains a standard, even today, for many Africans, it is not surprising that in their eyes, the reality of modern justice suffers many deficits. Litigants speak national languages, while modern justice is rendered and administered in French or English. Litigants are often not found and cannot be brought to justice; they need to use "interpreters" who sometimes barely understand the languages they translate or are simply incompetent or often deliberately commit "errors"; more often than not, judgments are not enforced by authorities. In all respects, the distances between individuals and modern justice are geographical and cultural; the result is that people do not believe in a justice system perceived - rightly or wrongly - to be tuned for wealthy citizens.

In the light of the above, it can probably be said that some of the difficulties affecting contemporary justice in Africa flow from the discrepancy between the modern and the traditional systems. Modern justice is perceived as complex and far from the sociological realities of the population. The fear of administrative authorities lingers; litigants fear retaliation from the state or persons in power since in traditional societies, one cannot challenge the chief or the King. More specifically, outside urban areas, judges are ignorant of local law in local matters and the applicable law is for all purposes foreign to litigants, while the influence of traditional authorities over their members is felt. In short, individuals relating to the simplicity of traditional societies feel foreign in a justice system which favours alien and complex norms rather than outcomes drawn from well understood norms and principles aimed at preserving cohesion, harmony and collective values.

The different social functions of justice impose a certain form of obsolescence on the modern justice system while, at the same time, not allowing - officially at least - traditional justice to reemerge as an alternative, especially in non-urban societies. The challenge is to reinitialise traditional justice systems with a view to merging traditional as well as modern values within society. 
It must be concluded from the above that elements of traditional customs and processes have survived in modern times and largely influence the law and the way they are applied in today's African countries. However, one must also conclude that a certain alienation from traditional norms and values characterises the various African legal systems. It is not surprising then that some of Africa's traditional values are found in the African regional instrument in force for the last twenty years.

\section{CHARACTERISTICS OF THE AFRICAN CHARTER}

\section{A Human Rights in Africa Before the African Charter}

Ancient African societies did not ignore human rights; quite the contrary. ${ }^{16}$ Not surprisingly, human rights were centered on the notion of solidarity within the community. As previously mentioned, African law being of a conciliatory nature and community-centered, there is no notion as such of rights as protectors of individuals against the group. According to Keba Mbaye, rights borrowed from the form of rites, in that they have to be obeyed in a quasi-religious fashion. ${ }^{17}$

In pre-colonial Africa, many liberties co-existed, including liberty of religion (since many religions co-existed in traditional African societies), liberty of association, freedom of expression, the right to participate in affairs of the state, and freedom of circulation. These rights were not conceived and experienced in terms of conflicts: rather, in terms of group rights and also of responsibilities. ${ }^{18}$ Rights were often understood in terms of duties to others in order for the right to exist: for example, the right of the child to education corresponded with the duty of the extended family to provide education. ${ }^{19}$

In fact, some African researchers nowadays maintain that some of the rights enshrined in the Universal Declaration of Human Rights 1948 (UDHR) ${ }^{20}$ were already present in traditional African societies in pre-colonial Africa. ${ }^{21}$ Since most of the law followed oral tradition, it was transmitted from generation to generation by the griots. However, in at least one case, the text of a charter adopted in 1236 in Kouroukan Fuga (Kanbaga, Mali) was found. Article 5 read "[e]veryone is entitled to life and to the preservation of their physical integrity. Therefore, any attempt to deprive

16 Keba Mbaye Les Droits de l'Homme en Afrique (2 ed, Pedone, Pedone, 2002) 71.

17 Ibid, 72

18 Ibid, 73

19 See also Ougergouz, above n 2, 11.

20 Universal Declaration of Human Rights (10 December 1948) UN Doc GA/Res/217A (III).

21 Mutoy Mubiala Le Système Régional Africain de Protection des Droits de l'Homme (Bruylant, Bruxelles, 2005) 7 referring to M Seck "Le Symposium International sur la Charte Africaine des Droits de l'Homme et des Peuples" (1983) 1 Revue du Barreau 31. 
someone from his life is punished by death penalty". Article 9 read: "[c]hildren's education is the responsibility of the whole society. Paternal authority is therefore exercised by all". ${ }^{22}$

In colonial Africa, things changed considerably from the moment colonial powers imposed their will and legal systems. Overall, two groups were distinguished: the natives on the one hand and the others (citizens). In many areas, 'good' natives were allowed to obtain citizenship privileges and rights (in Belgian Congo, in the Colonial Charter of 1908 and Senegal for four communes: SaintLouis, Dakar, Rufisque and Gorée). In all other areas, one generally notes the existence of binary systems where the natives had little or no rights. It meant that, for all purposes, Africans certainly did not identify with the "rights" approach put forward by colonial authorities. It is not surprising, in that context, that the "natives" did not consider themselves concerned by the principles of the UDHR when they appeared on the world stage in 1948.

Things changed slowly in post-colonial Africa. The history of the growing importance of bills of rights on the African continent has been written elsewhere. Each country has a different story to tell. For some countries, bills of rights were imposed by colonial powers before surrendering jurisdiction; for others, some time has had to pass after independence. ${ }^{23}$ What appears to be clear is that the presence of cultural factors explains their rapid emergence or not as does, among other things, the local legal environment. In almost all cases, mixed legal systems were in place (influenced by the Dutch, British, French, or Belgians) and superimposed on the tribal (or traditional) legal foundations.

\section{B The African Charter on Human Rights and People's Rights}

In 1961, a meeting was held in Lagos ${ }^{24}$ where jurists from all over Africa met to discuss issues relating to the Rule of Law. ${ }^{25}$ It recommended the adoption of an African Charter of Human Rights

22 Mubiala, above n 21, 8.

23 Charles O H Parkinson Bills of Rights and Decolonization, The Emergence of Domestic Human Rights Instruments in Britain's Overseas Territories (Oxford University Press, Oxford, 2007).

24 African Conference on the Rule of Law, Lagos, 1961.

25 The Law of Lagos declared:

(1) That the principles embodied in the Conclusions of the Conference which are annexed hereto should apply to any society, whether free or otherwise, but that the rule of law cannot be fully realised unless legislative bodies have been established in accordance with the will of the people who have adopted their constitution freely;

(2) That in order to maintain adequately the rule of law all governments should adhere to the principle of democratic representation in their legislatures;

(3) That fundamental Human Rights, especially the right to personal liberty, should be written and entrenched in the constitutions of all countries and that such personal liberty should not in peacetime be restricted without trial in a court of law; 
("the Charter"). ${ }^{26}$ It took another twenty years before it was finally adopted: the Banjul Declaration was adopted on 27 June 1981 and came into force five years later, on 21 October 1986. ${ }^{27}$ In many respects, the Charter is an original regional instrument which stresses a few characteristics of African society. In that respect, it reflects the values which were considered essential to the protection of rights on the African continent. By the scope of its application, it was of course not restricted to Francophone countries, but aimed at covering all the countries forming the African continent, whatever the language, ethnicity, culture or religion.

The Charter's preamble stressed the importance of the "historical tradition and the values of African civilization" and that these should inspire the concept not only of human rights but also that of peoples' rights. The preamble also indicated that in the protection of rights exists corresponding duties; it also declared the right to development, insisting on the necessary link between civil and political rights on the one hand and the satisfaction of economic, social and cultural rights on the other. It reads: ${ }^{28}$

Taking into consideration the virtues of their historical tradition and the values of African civilization which should inspire and characterize their reflection on the concept of human and peoples' rights;

Recognizing on the one hand, that fundamental human rights stem from the attributes of human beings which justifies their national and international protection and on the other hand that the reality and respect of peoples rights should necessarily guarantee human rights;

Considering that the enjoyment of rights and freedoms also implies the performance of duties on the part of everyone;

Convinced that it is henceforth essential to pay a particular attention to the right to development and that civil and political rights cannot be dissociated from economic, social and cultural rights in their conception as well as universality and that the satisfaction of economic, social and cultural rights is a guarantee for the enjoyment of civil and political rights.

(4) That in order to give full effect to the Universal Declaration of Human Rights of 1948, this Conference invites the African governments to study the possibility of adopting an African Convention of Human Rights in such a manner that the Conclusions of this Conference will be safeguarded by the creation of a court of appropriate jurisdiction and that recourse thereto be made available for all persons under the jurisdiction of the signatory states;

(5) That in order to promote the principles and the practical application of the rule of law, the judges, practising lawyers and teachers of law in African countries should take steps to establish branches of the International Commission of Jurists.

26 African Charter of Human Rights (27 June 1981) 1520 UNTS 217. See Mbaye, above n 16, 78.

27 For the history of the vision behind the Charter and the debate which led to the adoption of the Charter, see ibid, 169.

28 African Charter, above n 26. 
Article 18 of the Charter stresses the role of the family as "the natural unit and basis of society" and affirms the role of the state with regard to the health and moral wellbeing of the family. Interestingly enough, article 18 adds that "[t]he State shall have the duty to assist the family which is the custodian of morals and traditional values recognized by the community", putting forward the notion of traditional values. Article 29(1) defines the corresponding duty for every individual "to preserve the harmonious development of the family and to work for the cohesion and respect of the family; to respect his parents at all times, to maintain them in case of need". ${ }^{29}$

Chapter II of the Charter defines the duties of every individual; they include duties towards the family, but also towards society as well as the state and "other legally recognized communities and the international community". ${ }^{30}$ Article 29(7) of the Charter insists on the preservation of positive African cultural values and makes it a duty for the individual to preserve and strengthen them. It reads:

The individual shall also have the duty.... to preserve and strengthen positive African cultural values in his relations with other members of the society, in the spirit of tolerance, dialogue and consultation and, in general, to contribute to the promotion of the moral well being of society...

We have not found any instance where article 29(7) has been applied so far by the Commission. The Charter is thus an original instrument which enshrines values which are typical of African societies, in insisting on the importance of the family, of traditional values as well as the duties every individual has with regard to the affirmation of human rights.

Of course, the issue of the effective implementation of the rights guaranteed by the Charter in the national laws of different African countries can be raised. It is generally already quite difficult, especially for rural populations speaking national languages and neither French nor English, to understand the rule of law in a society governed by the oral culture. ${ }^{31}$ Combined with the fact that regional (and international) instruments are not necessarily integrated into the local law of different countries, the effective application of the Charter is somewhat challenging. The net result is a rather large deficit in human rights culture in contemporary Africa.

How can the promotion of human rights be encouraged in order to fight inertia? One stimulating idea is to work on the historico-cultural legitimisation of human rights. Ideally, if it is possible to

29 See also, in this respect, Art 27(1) of the African Charter, above n 26.

30 The African Charter, above n 27, ch II Art 27:

(1) Every individual shall have duties towards his family and society, the State and other legally recognized communities and the international community.

(2) The rights and freedoms of each individual shall be exercised with due regard to the rights of others, collective security, morality and common interest.

31 Mubiala, above n 21, 115. 
demonstrate the natural link between traditional values and modern human rights protected by contemporary national and international instruments, it will become easier to raise interest in human rights at the people's level. An experiment conducted in Mali a few years ago demonstrated the potential of this approach. It did so using the traditional Kourouka Fuga Charter as a departure point in educating individuals about their traditional and modern rights. It is suggested by some that the application of human rights standards in the application of local and customary norms should be attempted more systematically. ${ }^{32}$

\section{INTERNATIONAL HUMAN RIGHTS INSTRUMENTS AND FRANCOPHONE SUB-SAHARAN AFRICAN COUNTRIES}

Of course, Francophone African countries, like most countries of the international community, have in large part agreed to and ratified the main international instruments concerning human rights (see the below table). It is interesting to note that even small African Francophone island countries have in large part agreed to the main instruments.

\begin{tabular}{|c|c|c|}
\hline International Instrument & $\begin{array}{l}\text { Sub-Saharan Continental African } \\
\text { Francophone Countries }\end{array}$ & $\begin{array}{c}\text { Sub-Saharan Non-continental } \\
\text { African Francophone Countries }\end{array}$ \\
\hline $\begin{array}{l}\text { International Covenant on Civil and } \\
\text { Political Rights (1966) }\end{array}$ & All but Guinée-Bissau & All but Comores and Sao Tome \\
\hline $\begin{array}{l}\text { International Covenant on Economic, } \\
\text { Social and Cultural Rights (1966) }\end{array}$ & All & $\begin{array}{l}\text { All but Comores, Sao Tome and } \\
\text { Madagascar }\end{array}$ \\
\hline $\begin{array}{l}\text { International Convention on the } \\
\text { Elimination of All Forms of Racial } \\
\text { Discrimination (1965) }\end{array}$ & All but Djibouti and Guinée-Bissau & All but Sao Tome \\
\hline $\begin{array}{l}\text { Convention on the Elimination of All } \\
\text { Forms of Discrimination against } \\
\text { Women (1979) }\end{array}$ & All & All \\
\hline $\begin{array}{l}\text { Convention on the Rights of the Child } \\
\text { (1989) }\end{array}$ & All & All \\
\hline $\begin{array}{l}\text { Convention against Torture and Other } \\
\text { Cruel, Inhuman or Degrading } \\
\text { Treatment or Punishment (1984) }\end{array}$ & $\begin{array}{l}\text { All but Guinée-Bissau, République } \\
\text { Centre-Africiane, Rwanda and } \\
\text { Tchad }\end{array}$ & $\begin{array}{l}\text { All but Cap Verde, Madagascar and } \\
\text { Sao Tome }\end{array}$ \\
\hline $\begin{array}{l}\text { International Convention on the } \\
\text { Protection of the Rights of All } \\
\text { Migrant Workers and Members of } \\
\text { Their Families (1990) }\end{array}$ & $\begin{array}{l}\text { All but Burkina Faso, Guinea, Mali } \\
\text { and Senegal }\end{array}$ & All but Cap Verde and Seychelles \\
\hline
\end{tabular}

32 Ibid, 117.

33 Countries include Bénin, Burkina Faso, Burundi, Cameroon, Congo, Côte d'Ivoire, Djibouti, Gabon, Guinea, Guinea-Bissau, Guinea-Equatoriale, Mali, Mauritania, Niger, République Centre-Africaine, République démocratique du Congo, Rwanda, Sénégal, Tchad and Togo.

34 Countries include Cap Verde, Comores, Madagascar, Mauritius, Sao Tome \& Principe and Seychelles. 
The production of periodic reports varies enormously from one country to another: while a small number of countries produce their reports on time, most are late, or very late. This is considered a problem and the Organisation Internationale de la Francophonie (OIF; Organisation of Francophone Countries) is currently helping countries to meet their filing obligations.

As usual, the national reports are examined by the various committees in charge of the application of the respective instruments. The committees' findings for Francophone African countries are sometimes disturbing and identify some frankly unacceptable practices in terms of human rights. This is not the place to exhaustively analyse the committees' main findings. ${ }^{35}$ It is sufficient to give a few examples of the findings concerning children's rights, racial and ethnic discrimination.

In the case of children's rights, though all countries have ratified the Convention on the Rights of the Child, ${ }^{36}$ many have failed to enact the proper legislation. The main violations identified by the Committee relate to children belonging to vulnerable groups (such as refugees, handicapped, orphans). Their civil as well as economic, social cultural rights (including their right to education and health) are affected. In various countries, the Committee reports have also identified violations relating to the death penalty, corporal punishment, police and sexual abuse, as well as inhumane or degrading treatment and problems related to minor justice, kidnapping, soldier-children and child labour. Much work needs to be accomplished.

Concerning racial discrimination, most motives for discrimination described in the International Convention on the Elimination of All Forms of Racial Discrimination ${ }^{37}$ have been found in African countries. For instance, discrimination based on race was found in Guinea, Mauritania and in Côte d'Ivoire, while discrimination based on national origin was found in Zimbabwe, Cap Verde, Lesotho and again, in Côte d'Ivoire. Of course, despite warnings, the abusive use of the concept of Ivoirité (Ivorian citizenship) eventually led to major civil disturbance as well as a massive exodus of Ivoirians of Malian descent.

Over the years, the Committee concluded that major violations concerning ethnic discrimination had occurred in Senegal and in the non-Francophone countries of Botswana, Uganda, Liberia and Sudan. The Committee has generally found that women suffer from discrimination even if equality

35 Paul Tavernier Recueil Juridique des Droits de l'Homme en Afrique, 2000-2004 (Tome 1, Bruylant, Bruxelles, 2005) 53.

International Convention on the Elimination of All Forms of Racial Discrimination (21 December 1965) 60 UNTS 195 Art 1: "In this Convention, the term "racial discrimination" shall mean any distinction, exclusion, restriction or preference based on race, colour, descent, or national or ethnic origin which has the purpose or effect of nullifying or impairing the recognition, enjoyment or exercise, on an equal footing, of human rights and fundamental freedoms in the political, economic, social, cultural or any other field of public life." 
rights are guaranteed by countries' constitutions. The United Nations Committee on Discrimination Against Women has noted that in Congo, Cameroon and Guinea, traditional practices such as dowry, polygamy, forced marriages and genital mutilation are still prevalent. The Committee also concluded that in Sudan, customs and traditional practices were restricting women's rights, notably in family law and penal law with regard to their participation in public life. In most countries, women are also discriminated against by under-representation in all areas of public life. In République Démocratique du Congo and in Guinea, especially in rural zones, customs prevent women from owning real property and being able to inherit.

This bleak portrait of human rights in some African countries shows the distance between the letter of the Charter and of the international instruments adopted by various African countries, and reality. Many factors undoubtedly explain the formidable gap between law in books and law in action. Cultural differences as well as the absence of conciliation and discussion between competing legitimacies, in many individuals' eyes between the modern state's laws and the traditional customary requirements certainly suggests at least a partial explanation.

\section{CONCLUSION}

This brief portrait of the interrelationship between law, customary norms and traditions shows how complex law and legal cultures are in our societies. It has the merit of showing that in each of the world's societies from the North or South, the East or the West, it is often difficult to understand precisely the functioning of legal culture and the changes it can generate.

In the case of African countries, one finds an absence of a solid democratic culture; it results in a general dysfunction of state institutions. One obvious explanation is that the force of tradition resists the logico-rational logic of the Western (Northern) world. Africa still has to invent an authentic legal system which could rely on the strength of traditional customary systems and collective interests while allowing for the protection of traditional individual values enshrined in the various constitutions, in the Charter and the other international human rights instruments.

The vigour and probably greatest originality of the African legal system is its legal pluralism. Africans are, in their everyday life, constantly shifting from one normative order to another to an extent very few other individuals do around the globe. To a somehow simple society corresponds an eminently complex and rich normative order. The challenge of the 21st century for African legal systems will be that of inventing a genuine personality influenced both by the modernity of the international legal order and the strength of traditions adapted to the rapidly changing realities of African societies. ${ }^{38}$

38 For that perspective, see Camille Kuyu À la Recherché du Droit Africain du XXIième Siècle (Connaissances et Savoirs, Paris, 2005). 
